\title{
Produced water irrigation changes the soil mesofauna community in a semiarid agroecosystem
}

\author{
Raimundo Nonato Costa Ferreira \\ Olmar Baller Weber • Lindbergue Araujo Crisóstomo
}

Received: 15 December 2014 / Accepted: 14 July 2015

(C) Springer International Publishing Switzerland 2015

\begin{abstract}
The scarcity of water in semiarid regions requires alternative sources for irrigation to improve agricultural production. Here, we aimed to evaluate the effects of produced water from oil exploration on the structure of soil mesofauna during the dry and rainy seasons in irrigated sunflower and castor bean fields in a Brazilian semiarid region. Three irrigation treatments were applied on plots cultivated with castor beans and sunflowers: produced water treated by filtration (filtrated) or treated by reverse osmosis (reverse osmosis) and groundwater. The mesofauna under the biofuel crops was collected and identified during the dry and rainy seasons. Although the abundance and richness of the total fauna did not differ between seasons in sunflower plots, the community was altered. In castor beans, the abundance, richness, and community of mesofauna observed in plots irrigated with produced water differed from the groundwater treatment. Irrigation with produced water promotes important changes in
\end{abstract}

R. N. C. Ferreira $(\bowtie)$

Programa de Pós-Graduação em Ecologia e Recursos

Naturais, Universidade Federal, do Ceará, Fortaleza, Ceará

60455-760, Brazil

e-mail: nonatocferreira@gmail.com

O. B. Weber · L. A. Crisóstomo

Empresa Brasileira de Pesquisa Agropecuária, Fortaleza, Ceará 600511-110, Brazil

O. B. Weber

e-mail: olmar.weber@embrapa.br

L. A. Crisóstomo

e-mail: lindbergue.crisostomo@embrapa.br soil fauna community that justify their assessment for the maintenance and monitoring of agroecosystems.

Keywords Soil fauna - Community structure . Environmental management · Biofuel crop · Irrigation with produced water

\section{Introduction}

In semiarid climates, where the evaporation rate is higher than precipitation, irrigation is used to maintain plant production during periods of inadequate rainfall. However, not all semiarid regions have high-quality water available for irrigation, so the use of alternative sources, such as wastewater and produced water from industrial oil and gas plants, has been proposed (Allen and Robinson 1993; Johnston et al. 2008). The use of produced water was initially proposed for the irrigation of pastures and tree crops (Dejoia 2002; Johnston et al. 2008). However, the application or discharge of untreated and unmonitored produced water can alter the normal patterns of ecosystem functioning (Janke et al. 1992).

Wastewater and produced water negatively affect the soil and environment, mainly through the amounts of salts that they carry (Cutz-Pool et al. 2007; KöckSchulmeyer et al. 2011; Tabatabaei and Najafi 2009; Travis et al. 2012). Irrigation with produced water with a high concentration of sodium, chloride, and potassium can cause soil salinization (Al-Haddabi and Ahmed 2007; Melo et al. 2010; Neff 2002). The salinity and sodicity of the soil may reduce the efficiency of carbon 
use by microorganisms, with consequent changes in their biomass (Ibekwe et al. 2010; Rietz and Haynes 2003).

Reverse osmosis is typically used to reduce produced water salt content. However, the formation of biofilms on membranes requires the addition of a biocide and anti-scalant during the water treatment process (Melo et al. 2010), which may contaminate the water and compromise its quality. Thus, the biocide added to the reverse osmosis water treatment process could reduce, in the short term, the microbial activity in soil irrigated with that water (Lopes et al. 2014), which could affect the structure of the soil community.

The soil mesofauna in various ecosystems is influenced by factors such as soil moisture (Frampton et al. 2000; Lindberg et al. 2002; Morón-Ríos et al. 2010; Ukabi et al. 2009; Whitford et al. 1981) and vegetation cover (Bezemer et al. 2010; Ferreira et al. 2012; Franklin et al. 2005). Such factors are related to spatial and seasonal patterns, as well as microclimate variation and the quantity and quality of resources available for soil fauna (Wardle et al. 2006).

In semiarid regions, soil moisture levels fluctuate between seasons, with accompanying changes in the abundance and composition of soil organisms (Bedano and Ruf 2007; Wallwork 1972; Whitford et al. 1981). Under constant soil water levels, the mesofauna in irrigated agroecosystems is more stable between the dry and rainy seasons, especially in relation to the abundance of organisms, than native forests (MacKay et al. 1986). The low soil moisture level during the dry period has indirect effects on mesofauna through changes in vegetation and reduced activity and diversity of microorganisms in the soil (Acosta-Martínez et al. 2014; Bachar et al. 2010). Thus, seasonal fluctuations in the availability of resources to soil organisms can promote high seasonal variations in the abundance and activity of soil fauna (Wardle 2002).

Although the effects of humidity and vegetation cover on communities of soil fauna are well characterized (Ukabi et al. 2009; Whitford et al. 1981), almost nothing is known about the impact of water quality, especially produced water, on communities of soil fauna. Here, we aimed to evaluate how the quality of water obtained from oil exploration that is used for irrigation can affect the abundance, richness, and community structure of mesofauna in castor bean and sunflower biofuel crops during the dry and rainy seasons in a semiarid agroecosystem. We hypothesized that irrigation with produced water obtained by simple filtration or treated by osmosis could change the abundance and structure of the soil fauna community in comparison to using groundwater. In addition, we expected that these changes would differ in various crops and seasons.

\section{Materials and methods}

Study area

The study was conducted in the experimental area of the farm of the Belém (FZB) oil exploration field managed by Petrobras $\left(4^{\circ} 44^{\prime} 43.2^{\prime \prime} \mathrm{S}, 37^{\circ} 32^{\prime} 19.6^{\prime \prime} \mathrm{W}\right)$, located in the Brazilian semiarid region. The soil of the area was classified as Haplic Arenosol and the vegetation as seasonally dry tropical forest, known locally as caatinga (Sampaio 1995). The climate is hot and semiarid in the Köppen classification. The annual rainfall is less than $800 \mathrm{~mm}$ and is concentrated from January to May, with an annual mean temperature of 26 to $28^{\circ} \mathrm{C}$.

\section{Experimental design}

The study was conducted in irrigated areas cultivated with biofuel sunflower plants (Helianthus annuus L. 'BRS 321') or castor beans (Ricinus communis L. 'BRS Energia'). The sunflower and castor bean plots were irrigated with three water treatments: groundwater collected from the Açu aquifer (200-m depth), produced water treated by filtration (filtered), and produced water filtered and treated by reverse osmosis (reverse osmosis); all captured in FZB. Treatments with water management were composed of three replicates of $400 \mathrm{~m}^{2}$ for each crop and were randomly distributed in an area of $19,200 \mathrm{~m}^{2}$. Both plants were planted in two cropping cycles in the dry season (September 2012) and rainy season (March 2013, Fig. 1). The soil mesofauna was collected and identified in all areas in both seasons.

\section{Irrigation management}

A drip irrigation system was used to avoid water contamination among treatments. The system was automated and the daily amount of water supplied was estimated based on crop evapotranspiration and soil drainage, measured using a lysimeter column in the plots. Lysimeters were made by technicians of the Brazilian Agricultural Research Corporation (Embrapa, Ceará/Brazil) 
Fig. 1 Rainfall data collected between August 2012 and July 2013 by the meteorological station installed in the experimental area

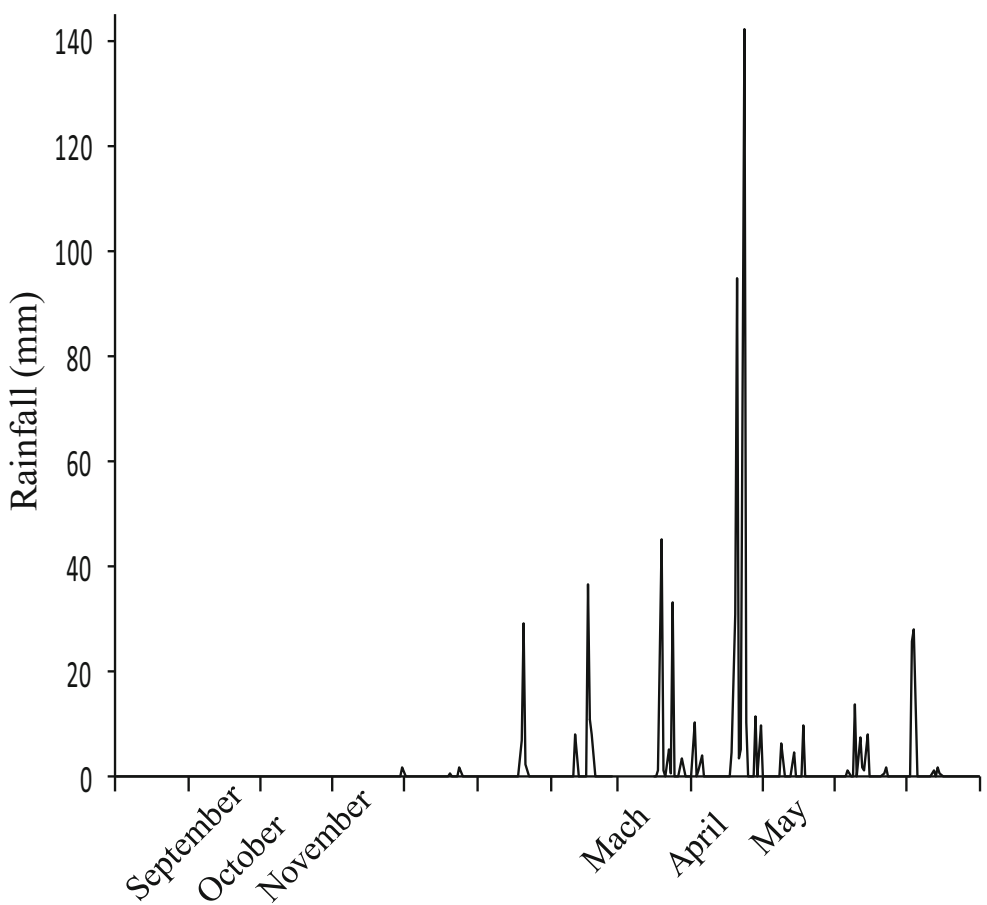

Dry season/2012
Rainy season/2012 using plastic columns (0.4-m diameter and $0.7 \mathrm{~m}$ deep) where the water drained daily was used to estimate the evapotranspiration of crops. The produced water for the filtered and reverse osmosis treatments had been previously separated in the industrial oil exploration plant (Melo et al. 2010). The water ion concentrations, electrical conductivities, and $\mathrm{pH}$ are shown in Table 1.

\section{Sampling and identification of soil mesofauna}

Undisturbed soil subsamples were collected using cylindrical soil samplers (10-cm diameter; $10-\mathrm{cm}$ depth). The subsamples were placed individually in plastic bags, stored in boxes, and immediately transported to a Berlese-Tullgren apparatus. Nine soil subsamples were collected in each $400-\mathrm{m}^{2}$ plot at different plant developmental stages (three samples at germination, three at flowering, and three immediately before the harvests, and all were $8 \mathrm{~m}$ distant from each other) forming a composite sample for each plot (Table 2). The soil mesofauna were extracted using the Berlese-Tullgren method modified by Franklin and Morais (2006) and classified at the level of order or suborder.
Table 1 Chemical composition of water used for the irrigation of castor beans and sunflowers, supplied by the Belém farm

\begin{tabular}{lllllllr}
\hline Waters/season & $\begin{array}{l}\mathrm{CE} \\
(\mathrm{dS} / \mathrm{m})\end{array}$ & $\mathrm{pH}$ & $\mathrm{Ca}$ & $\mathrm{Mg}$ & $\begin{array}{l}\mathrm{Na} \\
\mathrm{mmol}_{\mathrm{c}} / \mathrm{L}\end{array}$ & $\mathrm{K}$ & $\mathrm{Cl}$ \\
\hline Dry & & & & & & & \\
$\quad$ Filtrated & 2.51 & 8.84 & 0.11 & 0.65 & 24.15 & 0.68 & 13.74 \\
Reverse osmosis & 0.62 & 7.35 & 0.01 & 0.03 & 3.75 & 0.11 & 2.89 \\
Groundwater & 0.65 & 8.24 & 0.21 & 0.10 & 7.10 & 0.09 & 2.06 \\
Rainy & & & & & & & \\
$\quad$ Filtrated & 1.95 & 9.21 & 0.11 & 0.16 & 18.15 & 0.56 & 12.70 \\
$\quad$ Reverse osmosis & 0.38 & 7.52 & 0.11 & 0.07 & 2.95 & 0.05 & 1.21 \\
Groundwater & 0.66 & 8.34 & 0.21 & 0.11 & 6.23 & 0.08 & 2.41 \\
\hline
\end{tabular}


Table 2 Number of soil samples and subsamples collected in each irrigation treatment for mesofauna extraction in a Berlese-Tullgren apparatus

\begin{tabular}{llll}
\hline Samples/subsamples & Sunflower & Castor bean & Total \\
\hline Plots (composite samples) in each season & 3 & 3 & 6 \\
Subsamples in each plot in each season & 9 & 9 & 16 \\
Subsamples in dry season & 27 & 27 & 54 \\
Subsamples in rainy season & 27 & 27 & 54 \\
\hline
\end{tabular}

Holometabolic taxa were further separated into immature and adult organisms.

\section{Data analysis}

Analysis of variance (ANOVA) was used to evaluate the influence of irrigation treatments and season on mesofauna abundance and the number of taxa. The abundance data were normalized using a $\log x+1$ transformation. The water treatment means were compared by the Tukey post hoc test, at $5 \%$ probability. The sunflower and castor bean irrigation treatments were used to evaluate the effect of water on mesofauna community structure. The Bray-Curtis index was used to generate a similarity matrix among samples. Each matrix was subjected to a multivariate nonparametric analysis of variance (NP-MANOVA).

To generate a graphical representation of the composition/abundance of soil mesofauna across irrigation treatments, we used nonmetric multidimensional scaling (NMDS) ordered in two dimensions and calculated from the Bray-Curtis index. The scores resulting from the NMDS were plotted, and groupings of samples were evaluated. The statistical program R ( R Development Core Team 2014) was used for all analyses.

\section{Results}

We identified 3022 individuals distributed among 45 arthropod taxa in the studied area. Notably, we did not detect Oribatida, Thysanura, Symphyta, or Isopoda in the cultivated and irrigated areas. Some groups, such as Homoptera, Neuroptera larvae, and Poduromorpha, were identified only during the dry season crops, while Blattodea and Orthoptera were found only during the rainy season (Table 3).
The average number of organisms collected in sunflower plots was not significantly different between seasons (Table 4). Among irrigation treatments, abundance in the groundwater did not differ significantly from the other irrigation treatments. There were no differences in the richness of organisms in sunflower plots between seasons or between plots treated with groundwater and filtrated or reverse osmosis water (Table 4).

In castor bean plots, the abundance of organisms collected was significantly different between the seasons. In addition, the irrigation treatments influenced the abundance of soil organisms and there was an interaction with season (Table 4). In plots irrigated with groundwater, the abundance of organisms in the dry season differed from other irrigation treatments. In the rainy season, the abundance of organisms in soil receiving groundwater was similar to that in the other plots; however, the reverse osmosis treatment differed from filtered water (Table 5). The richness of soil mesofauna in castor bean plots was different between seasons and water treatments (Table 4). The number of taxa in groundwater treatments was lower in the dry season than in the rainy season. In the dry season, the richness of taxa was significantly higher in the groundwater treatment than the filtrated and reverse osmosis treatments. In the rainy season, the richness was not different from the reverse osmosis or filtered treatments (Table 5).

The composition of soil fauna communities in sunflower plots differed significantly between irrigation treatments, but depended on the season (Table 6). The NMDS analysis shows that the differences in mesofauna communities were primarily between reverse osmosis and the other treatments in the rainy season (Fig. 2). In castor bean plots, the community composition of soil fauna differed significantly between irrigation treatments and between seasons, with no significant interaction (Table 6). The plots that were irrigated with filtrated water and groundwater had similar mesofauna community structures in both cropping cycles. Treatment with 
Table 3 Relative abundance $(A b)$ and relative frequency $(F r)$ of soil organisms collected from nine castor bean and nine sunflower plots in the dry and rainy seasons

\begin{tabular}{|c|c|c|c|c|c|c|c|c|}
\hline \multirow[t]{3}{*}{ Taxa } & \multicolumn{4}{|c|}{ Dry season } & \multicolumn{4}{|c|}{ Rainy season } \\
\hline & \multicolumn{2}{|c|}{ Sunflower } & \multicolumn{2}{|c|}{ Castor bean } & \multicolumn{2}{|c|}{ Sunflower } & \multicolumn{2}{|c|}{ Castor bean } \\
\hline & $\mathrm{Ab}$ & $\mathrm{Fr}$ & $\mathrm{Ab}$ & $\mathrm{Fr}$ & $\mathrm{Ab}$ & $\mathrm{Fr}$ & $\mathrm{Ab}$ & $\mathrm{Fr}$ \\
\hline Astigmata & 19.7 & 100.0 & 25.2 & 100.0 & 12.8 & 66.7 & 21.8 & 100.0 \\
\hline Prostigmata & 10.3 & 44.4 & 13.7 & 100.0 & 9.0 & 44.4 & 33.7 & 100.0 \\
\hline Mesostigmata & 5.6 & 22.2 & 7.2 & 33.3 & 13.6 & 77.8 & 14.9 & 44.4 \\
\hline Acari & 35.6 & 100.0 & 46.1 & 100.0 & 35.4 & 100.0 & 70.4 & 100.0 \\
\hline Aranae & 0.0 & 0.0 & 1.6 & 44.4 & 5.2 & 77.8 & 1.2 & 100.0 \\
\hline Blatoidea & 0.0 & 0.0 & 0.0 & 0.0 & 0.0 & 0.0 & 0.1 & 11.1 \\
\hline Homoptera & 3.5 & 33.3 & 0.4 & 11.1 & 0.0 & 0.0 & 0.0 & 0.0 \\
\hline Coleoptera (larvae) & 24.6 & 88.9 & 8.0 & 88.9 & 2.3 & 66.7 & 2.6 & 77.8 \\
\hline Coleoptera & 18.0 & 88.9 & 11.5 & 100.0 & 3.8 & 55.6 & 0.5 & 44.4 \\
\hline Dermaptera & 0.4 & 11.1 & 0.2 & 11.1 & 0.0 & 0.0 & 0.1 & 11.1 \\
\hline Diplura & 0.4 & 11.1 & 0.0 & 0.0 & 1.5 & 44.4 & 0.5 & 55.6 \\
\hline Diptera (larvae) & 1.8 & 44.4 & 3.2 & 44.4 & 5.2 & 44.4 & 0.7 & 77.8 \\
\hline Entomobryomorpha & 7.4 & 55.6 & 8.7 & 88.9 & 14.2 & 66.7 & 6.9 & 88.9 \\
\hline Formicidae & 2.8 & 44.4 & 10.7 & 77.8 & 9.8 & 66.7 & 2.6 & 77.8 \\
\hline Hemiptera & 0.4 & 11.1 & 0.4 & 22.2 & 0.0 & 0.0 & 0.1 & 22.2 \\
\hline Hymenoptera (whithout formicidae) & 0.0 & 0.0 & 0.2 & 11.1 & 0.0 & 0.0 & 0.0 & 0.0 \\
\hline Isoptera & 1.1 & 22.2 & 5.8 & 33.3 & 0.0 & 0.0 & 0.0 & 0.0 \\
\hline Lepidoptera & 0.0 & 0.0 & 0.2 & 11.1 & 0.0 & 0.0 & 0.0 & 0.0 \\
\hline Lepidoptera (larvae) & 0.4 & 11.1 & 0.2 & 11.1 & 0.0 & 0.0 & 0.1 & 11.1 \\
\hline Neuroptera (larvae) & 0.4 & 11.1 & 0.0 & 0.0 & 0.0 & 0.0 & 0.0 & 0.0 \\
\hline Orthoptera & 0.0 & 0.0 & 0.0 & 0.0 & 0.0 & 0.0 & 0.1 & 11.1 \\
\hline Poduromorpha & 0.0 & 0.0 & 0.2 & 11.1 & 0.0 & 0.0 & 0.0 & 0.0 \\
\hline Pseudoscorpiones & 0.0 & 0.0 & 0.0 & 0.0 & 0.4 & 11.1 & 0.1 & 11.1 \\
\hline Psocoptera & 0.7 & 22.2 & 0.0 & 0.0 & 0.6 & 33.3 & 10.8 & 77.8 \\
\hline Symphypleona & 0.7 & 11.1 & 0.0 & 0.0 & 20.7 & 66.7 & 3.3 & 77.8 \\
\hline Thysanoptera & 2.1 & 44.4 & 2.6 & 44.4 & 0.8 & 44.4 & 0.1 & 22.2 \\
\hline
\end{tabular}

reverse osmosis water resulted in distinct communities that further differed between seasons (Fig. 2).

\section{Discussion}

Here, we presented data on changes in soil mesofauna promoted by irrigation with produced water. The water composition can potentially induce chemical and/or physical changes in the soil, modifying microorganism communities (Ibekwe et al. 2010) and the growth and health of plants (Qadir et al. 2003). Although irrigation with produced water could promote soil salinization
(Al-Haddabi and Ahmed 2007; Melo et al. 2010), in our study results, it changed the abundance of organisms in the soil cropped with castor bean during the dry season. Furthermore, changes in soil fauna abundance or richness were not evident between the produced water and groundwater treatments during either season in sunflower plots.

Salinity is known to affect some mesofauna groups, as observed for mites in semiarid regions of Australia, where there are species differences between high and low salinity soils (Noble et al. 1996). Organisms such as mites are affected by the number and size of soil pores (Nielsen et al. 2008). Filtered produced water contains 
Table 4 Summary of ANOVA testing the effects of season and irrigation treatments on the log-transformed abundance and richness of soil organisms in sunflower and castor bean cultivation

\begin{tabular}{|c|c|c|c|c|c|c|c|}
\hline \multirow[t]{2}{*}{ Variables } & \multirow[b]{2}{*}{ Df } & \multicolumn{3}{|c|}{ Abundance } & \multicolumn{3}{|c|}{ Richness } \\
\hline & & $F$ & $p$ value & Mean (Sq) & $F$ & $p$ value & Mean $(\mathrm{Sq})$ \\
\hline \multicolumn{8}{|l|}{ Sunflower } \\
\hline Season & 1 & 2.035 & 0.179 & 24.110 & 0.645 & 0.438 & 2.722 \\
\hline Irrigation & 2 & 0.921 & 0.424 & 10.920 & 0.645 & 0.542 & 2.722 \\
\hline Season $\times$ irrigation & 2 & 1.350 & 0.296 & 16.000 & 0.645 & 0.543 & 2.721 \\
\hline Residuals & 12 & & & 11.850 & & & 4.222 \\
\hline \multicolumn{8}{|l|}{ Castor bean } \\
\hline Season & 1 & 12.005 & 0.005 & 83.720 & 6.429 & 0.026 & 6.006 \\
\hline Irrigation & 2 & 11.737 & 0.002 & 81.850 & 11.514 & 0.002 & 10.757 \\
\hline Season $\times$ irrigation & 2 & 4.574 & 0.033 & 31.900 & 0.086 & 0.918 & 0.080 \\
\hline Residuals & 12 & & & 6.970 & & & 0.934 \\
\hline
\end{tabular}

The numbers in bold indicate significant effects

high $\mathrm{Na}$ content and may reduce soil porosity (AlHaddabi and Ahmed 2007). Soils with high salinity affect populations of microorganisms that are less diverse and less-efficient at carbon source utilization (Ibekwe et al. 2010; Rietz and Haynes 2003). During the rainy season, the accumulated salts from filtered produced water in the soil may be leached, removing any effects on the structure of mesofauna.

Lopes et al. (2014), studying the short-term effects of produced water on microorganism activity, observed larger populations of filamentous fungi when soils were irrigated with filtered produced water and groundwater than with water treated with reverse osmosis in this same study area. Mesofauna groups that are essentially scavengers and microbivores increase their abundance

Table 5 Tukey post hoc tests comparing the means of soil fauna among groundwater, reverse osmosis, and filtered treatments in castor bean cultivation

\begin{tabular}{|c|c|c|c|c|}
\hline \multirow[t]{2}{*}{ Treatments } & \multicolumn{2}{|l|}{ Abundance } & \multicolumn{2}{|l|}{ Richness } \\
\hline & $\begin{array}{l}\text { Dry } \\
\text { season }\end{array}$ & $\begin{array}{l}\text { Rainy } \\
\text { season }\end{array}$ & $\begin{array}{l}\text { Dry } \\
\text { season }\end{array}$ & $\begin{array}{l}\text { Rainy } \\
\text { season }\end{array}$ \\
\hline Groundwater & $17.360 \mathrm{Aa}$ & 17.610 Aab & $6.470 \mathrm{Aa}$ & $7.390 \mathrm{Ba}$ \\
\hline $\begin{array}{l}\text { Reverse } \\
\text { osmosis }\end{array}$ & $8.630 \mathrm{Ab}$ & $12.000 \mathrm{Ab}$ & $3.680 \mathrm{Ab}$ & $4.850 \mathrm{Aa}$ \\
\hline Filtered & $10.780 \mathrm{Ab}$ & $20.100 \mathrm{Ba}$ & $4.620 \mathrm{Ab}$ & $6.010 \mathrm{Aa}$ \\
\hline
\end{tabular}

Means followed by the same uppercase letter in rows and lowercase in columns did not have significant $(P<0.05)$ pairwise differences among treatments when there is greater availability of fungi in the soil, which subsequently affects higher trophic levels (de Ruiter et al. 1995; Remén et al. 2010; Schneider and Maraun 2005).

In the produced water treatment process, the addition of glutaraldehyde, which is toxic for some organisms (Leung 2001), during the desalinization process of reverse osmosis (Melo et al. 2010) could decrease the microbial activity of the soil (Lopes et al. 2014). On our plots, we observed changes in the abundance, richness, and structure of the mesofauna. Microorganisms are an important factor on mesofauna in soil food webs

Table 6 Summary of nonparametric multivariate analysis of variance (NP-MANOVA) based on 1000 permutations among the mesofauna structure from the Bray-Curtis index with seasonal and irrigation treatments on crops of sunflowers and castor beans

\begin{tabular}{lllll}
\hline Variables & Df & $F$ model & $R^{2}$ & $p$ value \\
\hline Sunflower & & & & \\
$\quad$ Season & 1 & $\mathbf{6 . 0 0 9}$ & 0.217 & $\mathbf{0 . 0 0 1}$ \\
$\quad$ Irrigation & 2 & $\mathbf{2 . 4 8 3}$ & 0.179 & $\mathbf{0 . 0 0 6}$ \\
$\quad$ Irrigation $\times$ season & 2 & $\mathbf{2 . 3 4 6}$ & 0.170 & $\mathbf{0 . 0 1 7}$ \\
$\quad$ Residuals & 12 & & 0.434 & \\
Castor beans & & & & \\
$\quad$ Season & 1 & $\mathbf{1 0 . 5 3 1}$ & 0.340 & $\mathbf{0 . 0 0 1}$ \\
$\quad$ Irrigation & 2 & $\mathbf{2 . 6 3 1}$ & 0.170 & $\mathbf{0 . 0 0 8}$ \\
$\quad$ Irrigation $\times$ season & 2 & 1.599 & 0.103 & 0.115 \\
$\quad$ Residuals & 12 & & 0.387 & \\
\hline
\end{tabular}

The numbers in bold indicate significant effects 


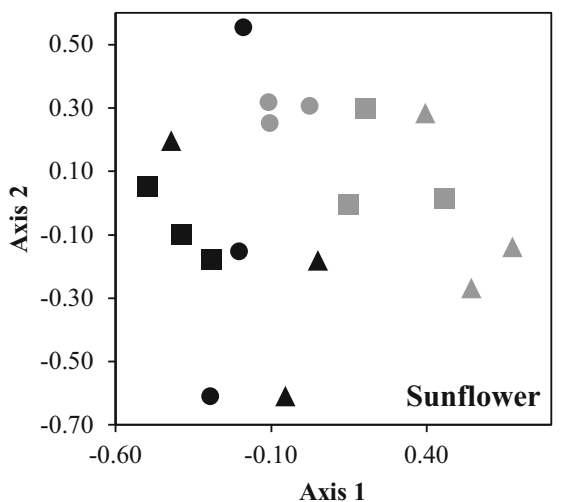

Fig. 2 Ordination of soil mesofauna in two-dimensional NMDS based on Bray-Curtis for sunflower (stress 0.19) and castor bean (stress 0.15 ) plots. Black points represent the dry season and gray points represent the rainy season. The triangles represent samples

(Berg et al. 2001; de Ruiter et al. 1995). It is believed that these factors have an indirect effect on the composition and abundance of soil mesofauna.

Two possible explanations for the differences in the structure of the soil community between different cropping cycles are as follows: (1) salts and other chemicals have accumulated in the soil during the second crop cycle and (2) the effect of the rainy season in the semiarid region. The increase in the concentration of salts in the soil (Elkins and Whitford 1984; Noble et al. 1996), as well as biocides such as glutaraldehyde (Leung 2001), during the dry season may have an effect (directly or indirectly) on some mesofauna organisms. This effect may be due to changes in the physicochemical characteristics of the soil microfauna or changes to the food web (Bezemer et al. 2010; de Ruiter et al. 1994; Rietz and Haynes 2003), based on the principle that changes in resource quality may modify the patterns of communities of soil organisms (Berg 2010).

Although there was no discrepancy in the seasonal availability of water in the cultivated irrigated area, we found that the mesofauna changed between seasons. Therefore, we propose that the mesofauna organisms present in the native forest and around the experimental area may have served as a source for the dispersal of organisms to more cultivated soils during the rainy season (Ettema and Wardle 2002; Pulliam 1988). It is noted that many soil fauna organisms can enter a state of quiescence or cryptobiosis during the dry period or tend to hatch eggs only in the rainy season, which results in their apparent absence during the dry season (MacKay et al. 1987). In addition, fungi that serve as food for many animals are inactive during the dry season (Whitford 1988).

Oribatid mites were absent from the fields of both types of crops. In fact, they are sensitive to soil management in semiarid environments (BoschSerra et al. 2014). Changes in the composition of mesofauna in agroecosystems can be associated with the type of soil and crop management (Bedano et al. 2006; Crossley et al. 1992; Domínguez et al. 2013; Lalley et al. 2006). Compared to native forests, cultivation potentially alters food webs and microhabitats that reduce the diversity and abundance of some groups of soil organisms (Bedano et al. 2006; de Ruiter et al. 1994; Wardle et al. 1995).

\section{Conclusions}

Irrigation with produced water promotes important changes in soil fauna structure that justify its assessment for the maintenance and monitoring of agroecosystems. To our knowledge, this is the first evidence of how the mesofauna structure is influenced by the quality of water used for irrigation. In semiarid regions, seasonal effects naturally induce variations in the composition and abundance of soil organisms, even if the areas are irrigated. The responses of soil fauna to differences in season differ between the land-use types. 
Acknowledgments This study was financially supported by PETROBRAS. The authors thank CAPES (Coordenação de Aperfeiçoamento de Pessoal de Nível Superior) and Embrapa Agroindústria Tropical.

\section{References}

Acosta-Martínez, V., Cotton, J., Gardner, T., Moore-Kucera, J., Zak, J., Wester, D., \& Cox, S. (2014). Predominant bacterial and fungal assemblages in agricultural soils during a record drought/heat wave and linkages to enzyme activities of biogeochemical cycling. Applied Soil Ecology, 84, 69-82. doi: 10.1016/j.apsoil.2014.06.005.

Al-Haddabi, M., \& Ahmed, M. (2007). Land disposal of treated saline oil production water: impacts on soil properties. Desalination, 212(1-3), 54-61. doi:10.1016/j.desal.2006.09.019.

Allen, R. M., \& Robinson, K. (1993). Environmental aspects of produced water disposal. In Proceedings of Middle East oil show (pp. 1-16). Bahrain: Society of Petroleum Engineers. doi:10.2118/25549-MS.

Bachar, A., Al-Ashhab, A., Soares, M. I. M., Sklarz, M. Y., Angel, R., Ungar, E. D., \& Gillor, O. (2010). Soil microbial abundance and diversity along a low precipitation gradient. Microbial Ecology, 60(2), 453-61. doi:10.1007/s00248010-9727-1.

Bedano, J. C., Cantú, M. P., \& Doucet, M. E. (2006). Influence of three different land management practices on soil mite (Arachnida: Acari) densities in relation to a natural soil. Applied Soil Ecology, 32(3), 293-304. doi:10.1016/j.apsoil. 2005.07.009.

Bedano, J. C., \& Ruf, A. (2007). Soil predatory mite communities (Acari: Gamasina) in agroecosystems of Central Argentina. Applied Soil Ecology, 36(1), 22-31. doi:10.1016/j.apsoil. 2006.11.008.

Berg, M., De Ruiter, P., Didden, W., Janssen, M., Schouten, T., \& Verhoef, H. (2001). Community food web, decomposition and nitrogen mineralisation in a stratified Scots pine forest soil. Oikos, 94(1), 130-142. doi:10.1034/j.1600-0706.2001.09121.x.

Berg, M. P. (2010). Spatio-temporal structure in soil communities and ecosystem processes. In H. A. Verhoef \& P. J. Morin (Eds.), Community ecology: processes, models, and applications (pp. 69-79). New York: Oxford University Press. doi: 10.1093/acprof:oso/9780199228973.003.0007.

Bezemer, T. M., Fountain, M. T., Barea, J. M., Christensen, S., Dekker, S. C., Duyts, H., et al. (2010). Divergent composition but similar function of soil food webs of individual plants: plant species and community effects. Ecology, 91(10), 3027-36.

Bosch-Serra, À. D., Padró, R., Boixadera-Bosch, R. R., Orobitg, J., \& Yagüe, M. R. (2014). Tillage and slurry overfertilization affect oribatid mite communities in a semiarid Mediterranean environment. Applied Soil Ecology, 84, 124 139. doi:10.1016/j.apsoil.2014.06.010.

Crossley, D. A., Mueller, B. R., \& Perdue, J. C. (1992). Biodiversity of microarthropods in agricultural soils: relations to processes. Agriculture, Ecosystems \& Environment, 40(1-4), 37-46. doi:10.1016/0167-8809(92)90082-M.
Cutz-Pool, L. Q., Palacios-Vargas, J. G., Castaño-Meneses, G., \& García-Calderón, N. E. (2007). Edaphic collembola from two agroecosystems with contrasting irrigation type in Hidalgo State, Mexico. Applied Soil Ecology, 36(1), 46-52. doi:10. 1016/j.apsoil.2006.11.009.

De Ruiter, P. C., Neutel, A. M., \& Moore, J. C. (1994). Modelling food webs and nutrient cycling in agro-ecosystems. Trends in Ecology \& Evolution, 9(10), 378-83. doi:10.1016/01695347(94)90059-0.

De Ruiter, P. C., Neutel, A. M., \& Moore, J. C. (1995). Energetics, patterns of interaction strengths, and stability in real ecosystems. Science (New York, N.Y.), 269(5228), 1257-60. doi:10. 1126/science.269.5228.1257.

Dejoia, A. J. (2002). Developing sustainable practices for CBMproduced water irrigation. The national association of state groundwater agencies. http://www.gwpc.org/meetings/ special/PW2002/Papers/Aaron_DeJoia_PWC2002.pdf. Accessed 18 Feb 2012.

Domínguez, A., Bedano, J. C., Becker, A. R., \& Arolfo, R. V. (2013). Organic farming fosters agroecosystem functioning in Argentinian temperate soils: evidence from litter decomposition and soil fauna. Applied Soil Ecology. doi:10.1016/j. apsoil.2013.11.008.

Elkins, N. Z., \& Whitford, W. G. (1984). The effects of high salt concentration on desert soil microarthropod density and diversity. Southwestern Naturalist, 30(2), 239-241.

Ettema, C., \& Wardle, D. A. (2002). Spatial soil ecology. Trends in Ecology \& Evolution, 17(4), 177-183. doi:10.1016/S01695347(02)02496-5.

Ferreira, R. N. C., Franklin, E., de Souza, J. L. P., \& de Moraes, J. (2012). Soil oribatid mite (Acari: Oribatida) diversity and composition in semi-deciduous forest fragments in eastern Amazonia and comparison with the surrounding savanna matrix. Journal of Natural History, 46(33-34), 2131-2144. doi:10.1080/00222933.2012.707245.

Frampton, G. K., Van den Brink, P. J., \& Gould, P. J. (2000). Effects of spring precipitation on a temperate arable collembolan community analysed using principal response curves. Applied Soil Ecology, 14(3), 231-248. doi:10.1016/S09291393(00)00051-2.

Franklin, E., Magnusson, W. E., Luizao, F., \& Luizão, F. J. (2005). Relative effects of biotic and abiotic factors on the composition of soil invertebrate communities in an Amazonian savanna. Applied Soil Ecology, 29(3), 259-273. doi:10.1016/j. apsoil.2004.12.004.

Franklin, E., \& Morais, J. W. (2006). Soil mesofauna in Central Amazon. In F. M. S. Moreira, J. O. Siqueira, \& L. Brossaard (Eds.), Soil biodiversity in Amazonian and other Brazilian ecosystems (Vol. 78, pp. 142-162). Wallingford: CABI Publishing.

Ibekwe, A. M., Poss, J. A., Grattan, S. R., Grieve, C. M., \& Suarez, D. (2010). Bacterial diversity in cucumber (Cucumis sativus) rhizosphere in response to salinity, soil $\mathrm{pH}$, and boron. Soil Biology and Biochemistry, 42(4), 567-575. doi:10.1016/j. soilbio.2009.11.033.

Janke, S., Schamber, H., \& Kunze, C. (1992). Effects of heating oil on the soil biological activity. Angewandte Botanik, 66, 42-45.

Johnston, C. R., Vance, G. F., \& Ganjegunte, G. K. (2008). Irrigation with coalbed natural gas co-produced water. Agricultural Water Management, 95(11), 1243-1252. doi: 10.1016/j.agwat.2008.04.015. 
Köck-Schulmeyer, M., Ginebreda, A., Postigo, C., López-Serna, R., Pérez, S., Brix, R., et al. (2011). Wastewater reuse in Mediterranean semi-arid areas: the impact of discharges of tertiary treated sewage on the load of polar micro pollutants in the Llobregat river (NE Spain). Chemosphere, 82(5), 670678. doi:10.1016/j.chemosphere.2010.11.005.

Lalley, J. S., Viles, H. A., Henschel, J. R., \& Lalley, V. (2006). Lichen-dominated soil crusts as arthropod habitat in warm deserts. Journal of Arid Environments, 67(4), 579-593. doi: 10.1016/j.jaridenv.2006.03.017.

Leung, H. W. (2001). Ecotoxicology of glutaraldehyde: review of environmental fate and effects studies. Ecotoxicology and Environmental Safety, 49(1), 26-39. doi:10.1006/eesa.2000. 2031.

Lindberg, N., Engtsson, J. B., \& Persson, T. (2002). Effects of experimental irrigation and drought on the composition and diversity of soil fauna in a coniferous stand. Journal of Applied Ecology, 39(6), 924-936. doi:10.1046/j.1365-2664.2002.00769.x.

Lopes, E. D. O. R., Weber, O. B., Crisóstomo, L. A., \& de Mattos, E. P. N. B. (2014). Short-term effects of produced water on microbial activity in semiarid soil. International Journal of Current Microbiology and Applied Sciences, 3(2), 295-403.

MacKay, W. P., Silva, S. I., \& Whitford, W. G. (1987). Diurnal activity patterns and vertical migration in desert soil microarthropods. Pedobiologia, 30, 65-71.

MacKay, W. P., Silva, S., Lightfoot, D. C., Inez Pagani, M., \& Whitford, W. G. (1986). Effect of increased soil moisture and reduced soil temperature on a desert soil arthropod community. American Midland Naturalist, 116(1), 45-56.

Melo, M., Schluter, H., Ferreira, J., Magda, R., Júnior, A., \& de Aquino, O. (2010). Advanced performance evaluation of a reverse osmosis treatment for oilfield produced water aiming reuse. Desalination, 250(3), 1016-1018. doi:10.1016/j.desal. 2009.09.095.

Morón-Ríos, A., Rodríguez, M. Á., Pérez-Camacho, L., \& Rebollo, S. (2010). Effects of seasonal grazing and precipitation regime on the soil macroinvertebrates of a Mediterranean old-field. European Journal of Soil Biology, 46(2), 91-96. doi:10.1016/j.ejsobi.2009.12.008.

Neff, J. M. (2002). Bioaccumulation in marine organisms: effect of contaminants from oil well produced water. Amsterdam: Elsevier.

Nielsen, U. N., Osler, G. H. R., van der Wal, R., Campbell, C. D., \& Burslem, D. F. R. P. (2008). Soil pore volume and the abundance of soil mites in two contrasting habitats. Soil Biology and Biochemistry, 40(6), 1538-1541. doi:10.1016/ j.soilbio.2007.12.029.

Noble, J. C., Whitford, W. G., \& Kaliszweski, M. (1996). Soil and litter microarthropod populations from two contrasting ecosystems in semi-arid eastern Australia. Journal of Arid Environments, 32(3), 329-346. doi:10.1006/jare.1996.0027.

Pulliam, R. (1988). Sources, sinks, and population regulation. The American Naturalist, 132(5), 652-661.

Qadir, M., Boers, T., Schubert, S., Ghafoor, A., \& Murtaza, G. (2003). Agricultural water management in water-starved countries: challenges and opportunities. Agricultural Water Management, 62(3), 165-185. doi:10.1016/S0378-3774(03)00146-X.
R Development Core Team. (2014). R: A language and environment for statistical computing. Viena: R Foundation for Statistical Computing.

Remén, C., Krüger, M., \& Cassel-Lundhagen, A. (2010). Successful analysis of gut contents in fungal-feeding oribatid mites by combining body-surface washing and PCR. Soil Biology and Biochemistry, 42(11), 1952-1957. doi:10.1016/ j.soilbio.2010.07.007.

Rietz, D., \& Haynes, R. (2003). Effects of irrigation-induced salinity and sodicity on soil microbial activity. Soil Biology and Biochemistry, 35(6), 845-854. doi:10.1016/S00380717(03)00125-1.

Sampaio, E. V. S. B. (1995). In S. H. Bullock, H. A. Mooney, \& E. Medina (Eds.), Seasonally dry tropical forests. Cambridge: Cambridge University Press. doi:10.1017/ CBO9780511753398.

Schneider, K., \& Maraun, M. (2005). Feeding preferences among dark pigmented fungal taxa ("Dematiacea") indicate limited trophic niche differentiation of oribatid mites (Oribatida, Acari). Pedobiologia, 49(1), 61-67. doi:10.1016/j.pedobi.2004. 07.010.

Tabatabaei, S. H., \& Najafi, P. (2009). Effects of irrigation with treated municipal wastewater on soil properties in arid and semi-arid regions. Irrigation and Drainage, 58(5), 551-560. doi:10.1002/ird.449.

Travis, M. J., Weisbrod, N., \& Gross, A. (2012). Decentralized wetland-based treatment of oil-rich farm wastewater for reuse in an arid environment. Ecological Engineering, 39, 81-89. doi:10.1016/j.ecoleng.2011.11.008.

Ukabi, S., Whitford, W. G., \& Steinberger, Y. (2009). Faunal pedturbation effects on soil microarthropods in the Negev Desert. Journal of Arid Environments, 73(10), 907-911. doi: 10.1016/j.jaridenv.2009.04.001.

Wallwork, J. A. (1972). Distribution patterns and population dynamics of the micro-arthropods of a desert soil in Southern California. Journal of Animal Ecology, 41(2), 291-310. doi: $10.2307 / 3470$.

Wardle, D. A. (2002). Communities and ecosystems: linking the aboveground and belowground components. In S. A. Levin \& H. S. Horn (Eds.), Monographs in population biology (Vol. 34). Princeton: Princeton University Press.

Wardle, D. A., Yeates, G. W., Watson, R. N., \& Nicholson, K. S. (1995). The detritus food-web and the diversity of soil fauna as indicators of disturbance regimes in agro-ecosystems. Plant and Soil, 170(1), 35-43.

Wardle, D., Yeates, G., Barker, G., \& Bonner, K. (2006). The influence of plant litter diversity on decomposer abundance and diversity. Soil Biology and Biochemistry, 38(5), 10521062. doi:10.1016/j.soilbio.2005.09.003.

Whitford, W. (1988). Abiotic controls on the functional structure of soil food webs. Biology and Fertility of Soils, 8(1), 1-6. doi:10.1007/BF00260508.

Whitford, W. G., Freckman, D. W., Elkins, N. Z., Parker, L. W., Parmalee, R., Phillips, J., \& Tucker, S. (1981). Diurnal migration and responses to simulated rainfall in desert soil microarthropods and nematodes. Soil Biology and Biochemistry, 13(5), 417-425. doi:10.1016/0038-0717(81)90087-0. 